\title{
Effect of temperature on emergence, survival and infectivity of cercariae of the marine trematode Renicola roscovita (Digenea: Renicolidae)
}

\author{
David W. Thieltges*, Jennifer Rick
}

Alfred Wegener Institute for Polar and Marine Research, Wadden Sea Station Sylt, Hafenstrasse 43, 25992 List, Germany

\begin{abstract}
Marine bivalves harbour a diversity of trematode parasites affecting population and community dynamics of their hosts. Although ecologically and economically important, factors influencing transmission between first (snail) and second (bivalve) intermediate hosts have rarely been studied in marine systems. In laboratory experiments, the effect of temperature $\left(10,15,20,25^{\circ} \mathrm{C}\right)$ was investigated on (1) emergence from snails, (2) survival outside hosts and (3) infectivity in second intermediate hosts of cercariae of the trematode Renicola roscovita (Digenea: Renicolidae), a major parasite in North Sea bivalves. Emergence of cercariae peaked at $20^{\circ} \mathrm{C}\left(2609 \pm 478\right.$ cercariae snail $^{-1}$ $\left.120 \mathrm{~h}^{-1}\right)$ and was considerably lower at $10^{\circ} \mathrm{C}(80 \pm 79), 15^{\circ} \mathrm{C}(747 \pm 384)$ and $25^{\circ} \mathrm{C}(1141 \pm 334)$. Survival time decreased with increasing temperature, resulting in $50 \%$ mortality of the cercariae after $32.8 \pm 0.6 \mathrm{~h}\left(10^{\circ} \mathrm{C}\right), 26.8 \pm 0.8 \mathrm{~h}\left(15^{\circ} \mathrm{C}\right), 20.2 \pm 0.5 \mathrm{~h}\left(20^{\circ} \mathrm{C}\right)$ and $16.6 \pm 0.3 \mathrm{~h}\left(25^{\circ} \mathrm{C}\right)$. Infectivity of $R$. roscovita cercariae in cockles Cerastoderma edule increased with increasing temperature and was highest at $25^{\circ} \mathrm{C}(42.6 \pm 3.9 \%)$. However, mesocosm experiments with infected snails and cockle hosts in small aquaria, integrating cercarial emergence, survival and infectivity, showed highest infection of cockles at $20^{\circ} \mathrm{C}\left(415 \pm 115\right.$ metacercariae host $\left.^{-1}\right)$, indicating $20^{\circ} \mathrm{C}$ to be the optimum temperature for transmission of this species. A field experiment showed metacercariae of $R$. roscovita to appear in $C$. edule with rising water temperature in April; highest infection rates were in August, when the water temperature reached $20^{\circ} \mathrm{C}$. Since another trematode species (Himasthla elongata; Digenea: Echinostomatidae) occurring at the experimental site showed a similar temporal pattern, trematode transmission to second intermediate bivalve hosts may peak during especially warm $\left(\geq 20^{\circ} \mathrm{C}\right) \mathrm{sum}$ mers in the variable climate regime of the North Sea.
\end{abstract}

KEY WORDS: Trematoda • Transmission • Cercariae • Temperature • Renicola roscovita . Himasthla elongata · Cerastoderma edule

Resale or republication not permitted without written consent of the publisher

\section{INTRODUCTION}

Marine molluscs are infected by a diverse assemblage of parasites with digenean trematodes being the dominant metazoan group (Lauckner 1980, 1983, Sindermann 1990). The adult stages develop in birds or fish, and larval stages utilise mostly snails as first, and bivalves, crustaceans or fish as second intermediate hosts. Marine trematodes exert various effects on their hosts and hence constitute an important population and community structuring factor in intertidal ecosystems (Lauckner 1984, Sousa 1991, Mouritsen \& Poulin 2002a, 2005).
Although ecologically important, knowledge on transmission of trematode infective stages between first and second intermediate hosts in marine systems is limited. In freshwater systems, temperature is a major factor influencing emergence, survival and infectivity of the cercarial transmission stages of trematodes (e.g. Evans 1985, Shostack \& Esch 1990, Pechenik \& Fried 1995, Lo \& Lee 1996, McCarthy 1999) and the few studies from marine systems indicate a similar trend. In Maritrema subdolum, which infects crustaceans as second intermediate host, temperature affected cercarial emergence and survival (Mouritsen 2002). In Crypotocotyle lingua, which infects fish as 
second intermediate host, temperature influenced survival of cercariae (Möller 1978). However, the effect of temperature on infectivity has not been studied in marine cercariae. No information exists on the transmission ecology of marine trematodes utilising bivalves as second intermediate hosts.

One of the dominating trematode species in bivalves on tidal flats in the North Sea is Renicola roscovita (Digenea: Renicolidae) (Werding 1969, Lauckner 1983, Buck et al. 2005, Thieltges et al. 2006). It uses the gastropod Littorina littorea as first intermediate host and a variety of bivalves as second intermediate host with cockles Cerastoderma edule and blue mussels Mytilus edulis being dominant. Definitive hosts are gulls Larus spp. and common eiders Somateria mollissima. Metacercarial infections by $R$. roscovita can reduce growth in M. edulis (Thieltges 2006), a bivalve species with high ecological and economic value.

This study was designed to investigate the influence of water temperature on (1) emergence from the first intermediate host, (2) survival between first and second intermediate hosts and (3) infectivity of cercariae of Renicola roscovita to the second intermediate host. This was done by laboratory experiments under 4 different temperature regimes $\left(10,15,20,25^{\circ} \mathrm{C}\right)$ using Littorina littorea as first and cockles Cerastoderma edule as second intermediate hosts. In addition, a field experiment was designed to detect seasonal patterns of infection.

\section{MATERIALS AND METHODS}

Parasite and host material. To obtain periwinkles Littorina littorea infected with Renicola roscovita, snails were randomly collected from the upper intertidal zone near the Wadden Sea Station Sylt, in the List tidal basin, in the northern Wadden Sea in April 2004. In the laboratory, collected periwinkles were screened for $R$. roscovita infections by exposing them in bowls filled with aerated seawater (approx. $20^{\circ} \mathrm{C}$ ) to intense light for several hours, and subsequently analysing the seawater for the presence of emerged cercariae. $R$. roscovita-infected periwinkles were isolated and kept in aerated aquaria (60 l) until the start of experiments. As second intermediate host for infection experiments, common cockles Cerastoderma edule were collected from a site in the lower intertidal zone in the List tidal basin where no trematode infections occurred. Cockles were kept in a large flow-through aquarium (3 m diameter, water height $50 \mathrm{~cm}$ ) with water temperature according to ambient conditions (approx. 10 to $15^{\circ} \mathrm{C}$ ).

Emergence of cercariae. Periwinkles were individually placed in small plastic jars (50 mm diameter) with $100 \mathrm{ml}$ aerated seawater, covered with a clear plastic lid and exposed to artificial daylight (5500 K, 5000 lux). For each treatment, 10 periwinkles were incubated in a constant temperature chamber, at 4 temperatures: $10,15,20$ and $25^{\circ} \mathrm{C}$. Every $12 \mathrm{~h}$ the seawater was exchanged with fresh, aerated seawater of the same temperature. The exchanged water was fixed with $10 \%$ formalin and the cercariae were counted in a zooplankton chamber (Bogorov chamber) under a dissection microscope. Experiments lasted for $5 \mathrm{~d}(120 \mathrm{~h})$.

Survival of cercariae. At each temperature, 300 cercariae of Renicola roscovita (average age of $2 \mathrm{~h}$ ) taken from a pool of first intermediate hosts were distributed in 10 small Petri dishes (60 mm diameter), filled with $50 \mathrm{ml}$ aerated seawater and exposed to artificial daylight $(5500 \mathrm{~K}, 5000$ lux). The Petri dishes (10 with 30 cercariae each) were incubated in constant temperature chambers at 4 temperatures: $10,15,20$ and $25^{\circ} \mathrm{C}$. At intervals of $2 \mathrm{~h}$, dead cercariae were counted until all cercariae were dead. The criterion for cercarial death was their failure to respond to a mechanical stimulus with a fine needle (Anderson \& Whitfield 1975, Evans 1985, McCarthy 1999).

Infectivity of cercariae. At each temperature, 30 cercariae (maximum age of $1 \mathrm{~h}$ ) from a pool of first intermediate hosts were placed in a Petri dish $(85 \mathrm{~mm}$ diameter) filled with $100 \mathrm{ml}$ aerated seawater and exposed to artificial daylight (5500 K, 5000 lux). 15 Petri dishes per temperature treatment $\left(10,15,20\right.$ and $\left.25^{\circ} \mathrm{C}\right)$ were incubated in constant temperature chambers. The experiment was started by addition of 1 small Cerastoderma edule (11 to $12 \mathrm{~mm}$ shell length) to each dish. After $24 \mathrm{~h}$ all cockles were put into fresh aerated seawater for another $24 \mathrm{~h}$ to allow full encystment of metacercariae. Finally, the cockleshells were removed, the tissue placed between 2 large glass slides and encysted metacercariae counted under a dissection microscope.

Mesocosm experiments. Five glass bowls $(90 \mathrm{~mm}$ diameter) were filled with approximately $3 \mathrm{~cm}$ deep sediment taken from the field. The bowls were filled with $400 \mathrm{ml}$ seawater, equipped with an air pump and exposed to artificial daylight (5500 K, 5000 lux). Five bowls each were incubated in constant temperature chambers at 4 temperatures: $10,15,20$ and $25^{\circ} \mathrm{C}$. To each bowl, 10 Cerastoderma edule were added. After $6 \mathrm{~h}$, when the cockles were buried, 3 infected Littorina littorina and pieces of sea lettuce Ulva spp. as food were added to each bowl. After $3 \mathrm{~d}$, the cockles were removed and left in seawater of the same temperature for another $24 \mathrm{~h}$ to allow full encystment of metacercariae. Following this, cockle tissues were screened for encysted metacercariae as described above.

Infection in the field. In January 2004, 1500 noninfected $1 \mathrm{yr}$ old Cerastoderma edule (13 to $15 \mathrm{~mm}$ ) were placed within an area of $2 \mathrm{~m}^{2}$. A fence of mesh wire (1 $\mathrm{cm}$ mesh size) of $5 \mathrm{~cm}$ height was set up to pre- 
vent cockles from dislodging and to mark the experimental area. Until December, in the middle of each month, 20 cockles were randomly chosen and examined for infection with metacercariae as described above. In addition to Renicola roscovita, metacercariae of Himasthla elongata (Digenea: Echinostomatidae) (also occurring in cockles at this site) were counted. Data on average water temperature of the water body in the basin were obtained from a long-term monitoring programme in the List tidal basin (provided by J. E. E. van Beusekom).

Statistical analysis. Differences in emergence, infectivity and intensity of Renicola roscovita in mesocosm experiments at the 4 temperatures were analysed using analysis of variance (1-way ANOVA). After testing for normality and homogeneity, data transformation was necessary for intensity data, which were log-transformed, and for infection success data, which were arcsine-transformed. Post-hoc calculations were performed with Tukey's HSD test (Day \& Quinn 1989). Survival of cercariae at the 4 temperatures was analysed using repeated-measurement ANOVA, since cercariae were subsequently counted in the same dish several times, resulting in nonindependence of the data. Prior to analysis, these data were arcsine-transformed.

\section{RESULTS}

Emergence of cercariae was significantly different at the 4 temperatures (Fig. 1 ; 1 -way ANOVA; $F_{3,36}=9.28$, $\mathrm{p}<0.001)$ and peaked at $20^{\circ} \mathrm{C}(2609 \pm 478$ cercariae snail $\left.^{-1} 120 \mathrm{~h}^{-1}\right)$. There was a significant difference in emergence between 20 and $10^{\circ} \mathrm{C}(80 \pm 79), 15^{\circ} \mathrm{C}(747 \pm$ $384)$ and $25^{\circ} \mathrm{C}(1141 \pm 334)$ (Tukey's HSD-test; $\mathrm{p}<$ $0.001, \mathrm{p}<0.01, \mathrm{p}<0.05$ respectively).

The survival time of cercariae decreased with increasing temperature (Fig. 2). A repeated-measure-

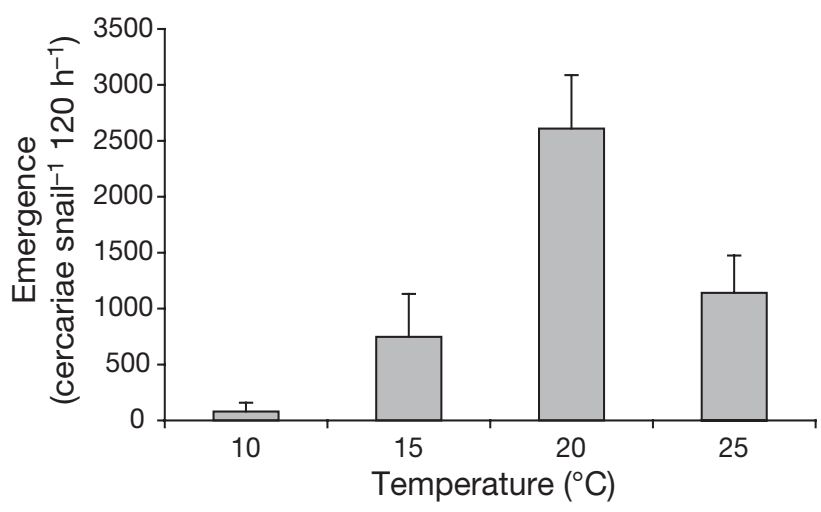

Fig. 1. Renicola roscovita. Mean (+SE) emergence of cercariae from snail first intermediate host Littorina littorea at 44 different temperatures. $\mathrm{n}=10$ snails at each temperature

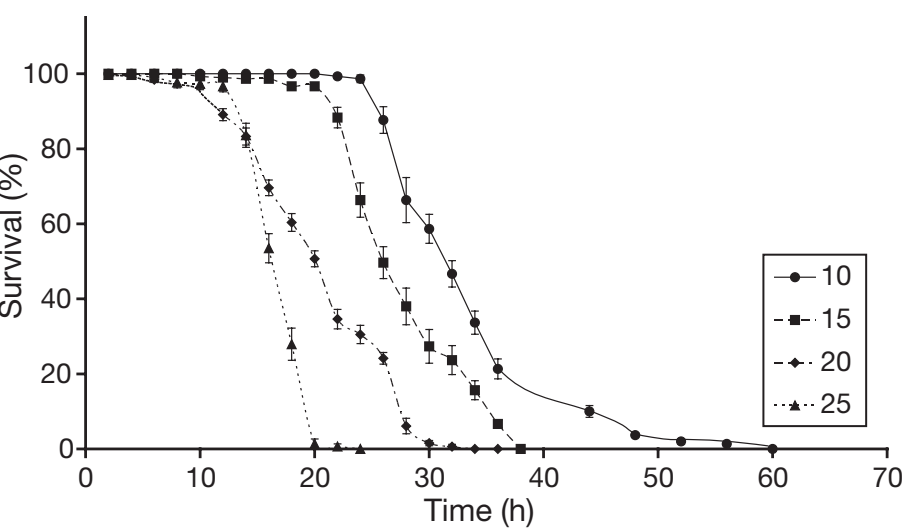

Fig. 2. Renicola roscovita. Mean $( \pm \mathrm{SE})$ survival percent of cercariae over $60 \mathrm{~h}$ at 4 different temperatures $\left({ }^{\circ} \mathrm{C}\right) . \mathrm{n}=10$ Petri dishes with 30 cercariae each

ment ANOVA revealed significant effects of temperature and time on survival and significant interactions (Table 1). The mean half life of cercariae (50\% dead) was $32.8 \pm 0.6 \mathrm{~h}\left(10^{\circ} \mathrm{C}\right), 26.8 \pm 0.8 \mathrm{~h}\left(15^{\circ} \mathrm{C}\right), 20.2 \pm 0.5 \mathrm{~h}$ $\left(20^{\circ} \mathrm{C}\right)$ and $16.6 \pm 0.3 \mathrm{~h}\left(25^{\circ} \mathrm{C}\right)$.

Infection success of cercariae increased with increasing temperature and showed significant differences among temperature regimes (Fig. 3; 1-way ANOVA; $\left.F_{3,56}=20.73 ; \mathrm{p}<0.001\right)$. This was due to significant differences in infection success between the $10^{\circ} \mathrm{C}$ treatment and all other treatments (Tukey's HSD-test; $\mathrm{p}<$ 0.001 each).

The infection intensity of metacercariae in the mesoscosm experiment was significantly different among the temperature treatments (Fig. 4; 1-way ANOVA $\left._{i} F_{3,16}=33.16 ; \mathrm{p}<0.001\right)$. This was due to statistical differences in intensity between the $10^{\circ} \mathrm{C}$ treatment and the $15,20,25^{\circ} \mathrm{C}$ treatments (Tukey's HSDtest; $\mathrm{p}<0.05$ for $15^{\circ} \mathrm{C}$ and $\mathrm{p}<0.001$ for the other temperatures) and differences among the $15^{\circ} \mathrm{C}$ treatment and the 20 and $25^{\circ} \mathrm{C}$ treatments $(\mathrm{p}<0.001)$.

In the field, infection of Cerastoderma edule with Renicola roscovita started in April and reached its

Table 1. Renicola ropscovita. Results of repeated-measurement ANOVA testing survival of cercariae over $60 \mathrm{~h}$ at 4 different temperatures $\left(10,15,20,25^{\circ} \mathrm{C}\right) . \mathrm{n}=10$ small dishes with 30 cercariae each

\begin{tabular}{|lrccc|}
\hline & df & MS & $F$ & $p$ \\
\hline Between subjects & & & & \\
Temp. & 3 & 16.9 & 638.9 & $<0.001$ \\
Error & 36 & 0.03 & & \\
Within subjects & & & & \\
Time & 29 & 14.4 & 2593.2 & $<0.001$ \\
Temp. $\times$ Time & 87 & 0.6 & 103.7 & $<0.001$ \\
Error (Time) & 1044 & 0.006 & & \\
\hline
\end{tabular}




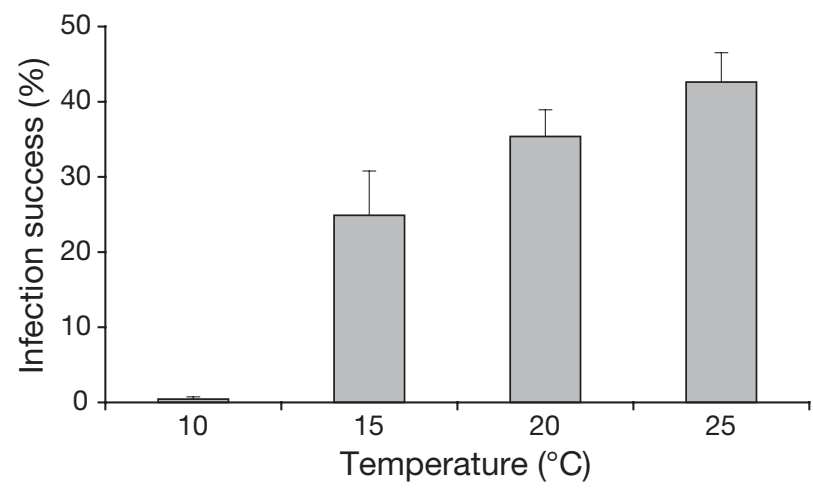

Fig. 3. Renicola roscovita. Mean (+SE) infection success percent of cercariae in cockle second intermediate hosts Cerastoderma edule at 4 different temperatures. $\mathrm{n}=15$ cockles exposed to 30 cercariae each

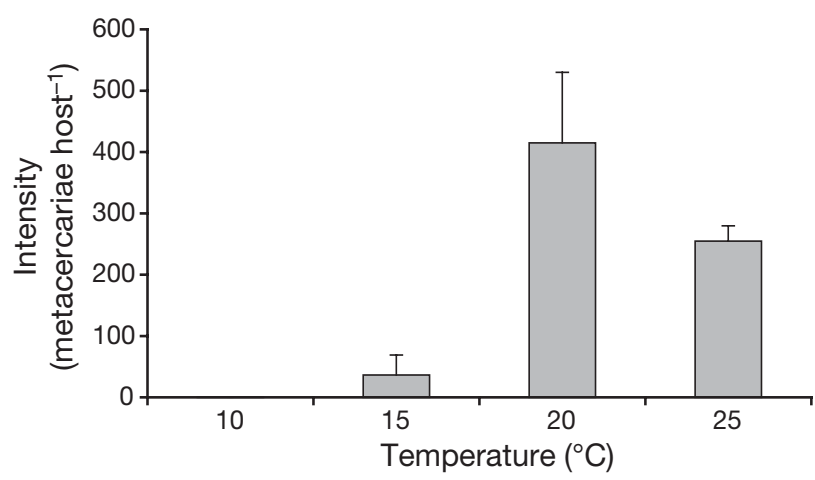

Fig. 4. Renicola roscovita. Mean (+SE) infection intensity (metacercariae per host) of cercariae in Cerastoderma edule in mescocosm experiments at 4 different temperatures. $n=5$ mesocosms, each containing 3 Littorina littorea (infected with $R$. roscovita) and 10 C. edule

highest intensity at the end of the summer (Fig. 5). In autumn and winter no new infections occurred. A similar pattern was observed for Himasthla elongata. Water temperature peaked in August at a maximum of $21.5^{\circ} \mathrm{C}$ (mean $19.6 \pm 0.3^{\circ} \mathrm{C}$ ) and was generally highest over the summer months (Fig. 5).

\section{DISCUSSION}

Water temperature had a strong effect on emergence, survival and infectivity of cercariae of Renicola roscovita. This indicates that transmission success may vary between years, depending on the North Atlantic climate regime.

Emergence of cercariae was highest at $20^{\circ} \mathrm{C}$. Since all snails were collected from the field at the same time (thus representing an average developmental condition of sporocysts within the population), temperature seems to trigger the emergence of cercariae and not

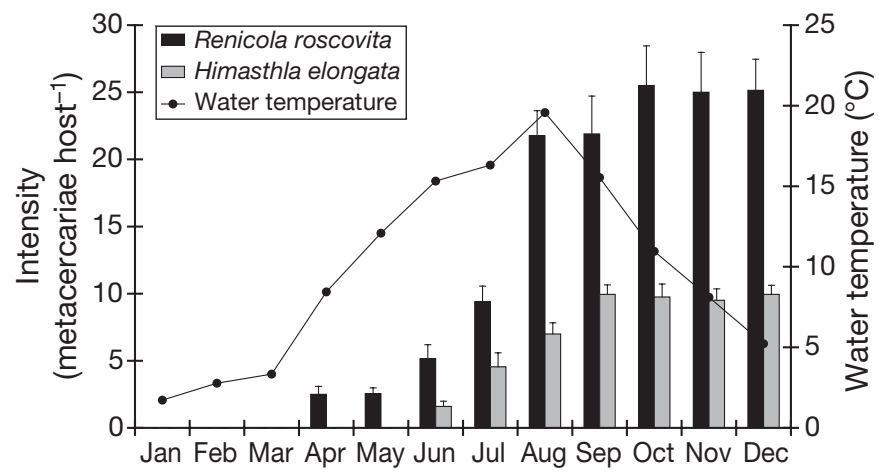

Fig. 5. Renicola roscovita and Himasthla elongata. Mean $(+\mathrm{SE})$ infection intensity of metacercariae in Cerastoderma edule in an experimental enclosure on a temperate tidal flat (bars) and mean monthly seawater temperature $\left({ }^{\circ} \mathrm{C}\right)$ (data points and lines) in List tidal basin from January to December 2004

just accelerate cercarial maturation (Ginetsinskaya 1988, Mouritsen 2002). Increase in emergence with increasing temperature has also been observed in other trematode-host systems (Lo \& Lee 1996, Lyholt \& Buchmann 1996, Mouritsen 2002). However, since emergence was considerably lower at $25^{\circ} \mathrm{C}$ than at $20^{\circ} \mathrm{C}$, there seems to exist an upper temperature limit for cercarial emergence in Renicola roscovita. In other trematode species such an upper limit has been suggested to be associated with an upper temperature tolerance of the intermediate hosts (Erasmus 1972, Lo \& Lee 1996). However, for $R$. roscovita, the upper temperature limits for the first intermediate host Littorina littorea and the 2 dominant second intermediate hosts Cerastoderma edule and Mytilus edulis are beyond $25^{\circ} \mathrm{C}$ (Hamby 1975, Newell 1979, Ansell et al. 1981, Gosling 1992). Hence, the observed emergence temperature optimum of $20^{\circ} \mathrm{C}$ for $R$. roscovita cercariae should result from advantages for the parasite's transmission success rather than host physiology.

The survival time of Renicola roscovita cercariae decreased with increasing temperature. Cercariae are assumed to have a restricted energy reserve in the form of glycogen (Anderson \& Whitfield 1975) which is presumably used up faster at high temperatures due to higher rates of cercarial activity (Pechenik \& Fried 1995). Decreased survival with increasing temperature was also shown for other trematode cercariae from marine (Möller 1978, Mouritsen 2002) and freshwater (e.g. Evans 1985, Shostack \& Esch 1990, Lyholt \& Buchmann 1996, McCarthy 1999) systems and seems (with a few exceptions (e.g. Lo \& Lee 1996) to be a universal phenomenon in trematode cercariae. The mean time until $50 \%$ mortality of $R$. roscovita cercariae ranged from $16.6 \mathrm{~h}\left(25^{\circ} \mathrm{C}\right)$ to $32.8 \mathrm{~h}\left(10^{\circ} \mathrm{C}\right)$. However, for the actual infection success of cercariae their functional longevity (time until cercariae, although still alive, are 
no longer available to infect a host) rather than their total survival time is important. This functional longevity is usually only 20 to $50 \%$ of the total survival time, since cercarial infectivity decreases with increasing age (Evans 1985, Lowenberger \& Rau 1994, Pechenik \& Fried 1995, McCarthy 1999). Hence, the mean functional longevity of $R$. roscovita is probably between 8 and 16 h, depending on ambient temperature.

Infectivity of Renicola roscovita cercariae was highest at $25^{\circ} \mathrm{C}$, presumably due to a temperature dependent increase in cercarial swimming activity resulting in a corresponding increase in the number of contacts between cercariae and host per unit time (Evans 1985). Additional to temperature mediated effects on cercarial behaviour, host behaviour is certainly also important. Bivalve activity and filtration intensity increases with rising temperature (Newell 1979) and since infections are mainly caused by inhaled cercariae (Montaudouin et al. 1998, Wegeberg et al. 1999) temperature dependent host behaviour should also increase infection success.

Although infectivity of cercariae of Renicola roscovita was highest at $25^{\circ} \mathrm{C}$, the mesocosm experiments, integrating emergence, survival and infectivity of cercariae at different temperatures, indicated that $20^{\circ} \mathrm{C}$ is an optimum temperature for transmission of $R$. roscovita. Besides potential synergistic effects of emergence, survival and infectivity at different temperatures in mesocosms, the presence of bivalve intermediate hosts might also have influenced the emergence of cercariae and thus have led to differential infectivity of cercariae: Mouritsen (2002) showed that second intermediate host exudates enhanced emergence of cercariae of Maritrema subdolum. A similar effect could occur in the $R$. roscovita-cockle system, but this remains to be investigated.

That $20^{\circ} \mathrm{C}$ is the optimal temperature for transmission of Renicola roscovita cercariae is supported by observations in the field experiment. Intensity of $R$. roscovita metacercariae in cockles was highest in August when the water temperature reached $20^{\circ} \mathrm{C}$. Hence, summer should be the main infective season for $R$. roscovita cercariae due to (1) temperature dependent development of sporocysts in the first intermediate hosts of snails (Möller 1978, Fagbemi 1984, Ataev 1991) and (2) a strongly temperature dependent emergence, survival and infectivity of cercariae when mature, as shown in our experiments. Another trematode species occurring at the experimental site, Himasthla elongata, showed a similar temporal pattern. This suggests that transmission of cercariae on temperate tidal flats generally peaks during summer. In contrast, the mean temperature of the water body is considerably lower in spring and autumn. However, in shallow waters and water remaining, at low tide (tide pools) temperature can strongly increase during sunny and calm days (Thieltges pers. obs.). Hence, shallow waters and tide pools should be hotspots for trematode infections on temperate tidal flats, where appropriate temperatures for transmission are regularly attained. This was also inferred from laboratory studies by Mouritsen (2002), and field experiments showed a higher trematode load in cockles in tidal pools compared to those in surrounding hummocks (Thieltges \& Reise 2006).

Summer temperatures in the vicinity of the North Atlantic vary considerably between years, largely depending on the North Atlantic climate oscillation (NAO) (Stenseth \& Ottersen 2004). The NAO is calculated as the deviance from the average sea level pressure difference between Iceland and the Azores. A positive NOA index results in high temperatures, strong winds and high precipitation in northern Europe and low temperatures in North America. A low NAO index has opposite effects. The NAO index fluctuates between years, resulting in different summer conditions. Hence, trematode transmission to second intermediate bivalve hosts may peak during particular warm summers under highly positive NAO conditions. Such conditions are predicted to arise more frequently in northern Europe under various climate change scenarios (Stenseth \& Ottersen 2004). Hence, a warming trend may lead to enhanced transmission on temperate tidal flats with a multitude of potential subsequent effects on host populations and communities (Marcogliese 2001, Mouritsen \& Poulin 2002b).

Acknowledgements. We thank K. Reise and M. Krakau for comments on the manuscript. J.E.E. van Beusekom is thanked for providing temperature data.

\section{LITERATURE CITED}

Anderson RWP, Whitfield PJ (1975) Survival characteristics of the free-living cercarial population of the ectoparasitic digenean Transversotrema patialensis (Soparker, 1924). Parasitology 70:295-310

Ansell AD, Barnett PR, Bodoy A, Masse H (1981) Upper temperature tolerances of some European molluscs: Cardium glaucum, C. tuberculatum and C. edule. Mar Biol 65: $177-183$

Ataev G (1991) Temperature influence on the development and biology of rediae and cercariae of Philophthalamus rhionica (Trematoda). Parazitologija 25:349-359

Buck B, Thieltges DW, Walter U, Nehls G, Rosenthal H (2005) Inshore-offshore comparison of parasite infestation in Mytilus edulis: implications for open ocean aquaculture. J Appl Ichthyol 21:107-113

Day RW, Quinn GP (1989) Comparisons of treatments after an analysis of variance in ecology. Ecol Monogr 59:433-463

Erasmus DA (1972) The biology of trematodes. University Press, Belfast 
Evans N (1985) The influence of environmental temperature upon transmission of the cercariae of Echinostoma liei (Digenea: Echinostomatidae). Parasitology 90:269-275

Fagbemi B (1984) The effects of environmental factors on the development, behaviour and survival of Paramphistomum microbothrium miracidia. Vet Parasitol 16:71-81

Ginetsinskaya TA (1988) Trematodes, their life cycles, biology and evolution. Amerind Publishing, New Delhi

Gosling E (ed) (1992) The mussel Mytilus: ecology, physiology, genetics, and culture. Elsevier, Amsterdam

Hamby RJ (1975) Heat effects on a marine snail. Biol Bull (Woods Hole) 149:331-347

Lauckner G (1980) Diseases of Mollusca: Gastropoda. In: Kinne O (ed) Diseases of marine animals, Vol I. General aspects, Protozoa to Gastropoda, John Wiley \& Sons, New York, p 311-424

Lauckner G (1983) Diseases of Mollusca: Bivalvia. In: Kinne O (ed) Diseases of marine animals, Vol II. Introduction, Bivalvia to Scaphopoda, Biologische Anstalt Helgoland, Hamburg, p 477-961

Lauckner G (1984) Impact of trematode parasitism on the fauna of a North Sea tidal flat. Helgol Meeresunters 37:185-199

Lo CT, Lee KM (1996) Pattern of emergence and the effects of temperature and light on the emergence and survival of heterophyid cercariae (Centrocestus formosanus and Haplorchis pumilio). J Parasitol 82:347-350

Lowenberger CA, Rau ME (1994) Plagiorchis elegans: emergence, longevity and infectivity of cercariae, and host behavioural modifications during cercarial emergence. Parasitology 109:65-72

Lyholt H, Buchmann K (1996) Diplostomum spathaceum: effects of temperature and light on cercarial shedding and infection of rainbow trout. Dis Aquat Org 25:169-173

Marcogliese DJ (2001) Implications of climate change for parasitism of animals in the aquatic environment. Can J Zool 79:1331-1352

McCarthy A (1999) The influence of temperature on the survival and infectivity of the cercariae of Echinoparyphium recurvatum (Digenea: Echinostomatidae). Parasitology 118:383-388

Möller H (1978) The effects of salinity and temperature on the development and survival of fish parasites. J Fish Biol 12: 311-323

Montaudouin X de, Wegeberg A, Jensen K, Sauriau P (1998) Infection characteristics of Himasthla elongata cercariae in cockles as a function of water current. Dis Aquat Org $34: 63-70$

Editorial responsibility: Albert Sparks,

Seattle, Washington, USA
Mouritsen K (2002) The Hydrobia ulvae-Maritrema subdolum association: influence of temperature, salinity, light waterpressure and secondary host exudates on cercarial emergence and longevity. J Helminthol 76:341-347

Mouritsen K, Poulin R (2002a) Parasitism, community structure and biodiversity in intertidal ecosystems. Parasitology 124:101-117

Mouritsen K, Poulin R (2002b) Parasitism, climate oscillation an the structure of natural communities. Oikos 97:462-468

Mouritsen K, Poulin R (2005) Parasites boost biodiversity and changes animal community structure by trait-mediated indirect effects. Oikos 108:344-350

Newell RC (1979) Biology of intertidal animals. Marine Ecological Surveys, Faversham

Pechenik J, Fried B (1995) Effect of temperature on survival and infectivity of Echinostoma trivolvis cercariae: a test of the energy limitation hypothesis. Parasitology 11: 373-378

Shostak AW, Esch GW (1990) Temperature effects on survival and excystment of cercariae of Halipegus occidualis (Trematoda). Int J Parasitol 20:95-99

Sindermann C (1990) Principle diseases of marine fish and shellfish: diseases of marine shellfish, Vol II, Academic Press, San Diego

Sousa WP (1991) Can models of soft-sediment community structure be complete without parasites? Am Zool 31: $821-830$

Stenseth NC, Ottersen G (eds) (2004) Marine ecosystems and climate change. The North Atlantic - a comparative perspective. Oxford University Press, Oxford

Thieltges DW (2006) Effect of infection by the metacercarial trematode Renicola roscovita on growth in intertidal blue mussel Mytilus edulis. Mar Ecol Prog Ser 319:129-134

Thieltges DW, Reise K (2006) Spatial heterogeneity in parasite infections at different spatial scales in an intertidal bivalve. Oecologia DOI 10. 1007/s00442-006-0557-2

Thieltges DW, Krakau M, Andresen H, Fottner S, Reise K (2006) Macroparasite community in molluscs at a tidal basin in the Wadden Sea. Helgol Mar Res DOI 10. 1007/s10152-006-0046-3

Wegeberg A, Montaudouin X de, Jensen K (1999) Effect of intermediate host size (Cerastoderma edule) on infectivity of cercariae of three Himasthla species (Echinostomatidae, Trematoda). J Exp Mar Biol Ecol 238:259-269

Werding B (1969) Morphologie, Entwicklung und Ökologie digener Trematoden-Larven der Strandschnecke Littorina littorea. Mar Biol 3:306-333

Submitted: December 22, 2005; Accepted: July 26, 2006

Proofs received from author(s): October 27, 2006 